Оригинални научни рад

614(497.5)"18"

doi:10.5937/zrpfns54-25627

Miro A. Gardǎ́, Ph.D., Full Professor

University J.J. Strossmayer University of Osijek

Faculty of Law Osijek

mgardas@pravos.hr

Slavko I. Čandrlić, Ph.D. student

University J.J.Strossmayer University of Osijek

Faculty of Law Osijek

slcandrlic@gmail.com

\title{
LEGISLATIVE REGULATION OF PUBLIC HEALTH IN CROATIA IN THE SECOND HALF OF THE $19^{\mathrm{TH}}$ CENTURY
}

Abstract: In the provisions of the 1868 Croatian-Hungarian Settlement, internal administration was seen as one of the autonomous areas that Croatia regulated on its own. Part of that was public health, which had been regulated in a very outdated manner up to that point. Appointing Ivan Mažuranić the Ban of Croatia paved way for substantial reforms in numerous areas of public and social life. Among other reforms, legal regulation of public health was proved to be necessary. In this paper we will attempt to present the legal framework regulating public health in Croatia, as well as use specific examples from the archival fonds of the Croatian State Archives in Osijek to portray how these laws were applied in everyday life.

Keywords: public health, reforms, Mažuranić, Osijek, Slavonia.

\section{INTRODUCTION}

Every country adopts certain legal measures administering the procedures in public health. Regulating the question of public health is one of the elementary features of communal living. The specificity of Croatia and Slavonia rests on the fact that, for many years, they were boundary points of Austrian Empire bordering Ottoman Empire and, as such, required special care and regulation considering the incursion of different contagious diseases from the outside. 
Also, there were several swamp areas in Slavonia and Croatia with very unhealthy climate that might have been the source of an epidemic break-out (swamps north and south of Osijek, Lonja field, etc.). For many years, the question of public health was regulated by Austrian i.e. Hungarian laws for areas belonging to the Hungarian part of the monarchy. Croatian-Hungarian Settlement opened opportunities for public health to be regulated in a new, modernized way.

Croatian-Hungarian Settlement represented the fundamental state law by which the Kingdom of Croatia-Slavonia and Kingdom of Hungary regulated their constitutional relations in 1868 .

Croatian-Hungarian Settlement regulated two types of affairs: autonomous and common Croatian-Hungarian affairs. Autonomous authorities were provided to handle autonomous affairs and common Croatian-Hungarian authorities were provided to deal with communal affairs.

According to Article 48 of the Settlement, autonomous affairs included judiciary, inner administration, public worship and teaching. Autonomous authorities were entitled to perform autonomous affairs: parliament, national government and the governor. National government included three departments, one of which was Department for Inner Affairs, responsible for public health affairs. ${ }^{1}$

Throughout the history, contagious diseases have left trace in human life. Death cases caused by contagious diseases have set back the development of certain cities and lead to demographic consequences in the affected area.

Diseases that affected people throughout the history were many: leprosy, typhoid, dysentery, syphilis, tuberculosis, malaria, measles, but two of them left the biggest consequences and caused the greatest fear- plague and cholera. ${ }^{2}$

Plague is a disease that has been mentioned since the earliest days of mankind and has left a trail in some of the oldest written monuments. Most probably the name "plague" hides several different diseases that were simply named together as plague by later authors and editors. Still, the traces of this disease date back to ancient times of human mankind.

\section{MEASURES OF THE AUSTRIAN GOVERNMENT IN PUBLIC HEALTH IN CROATIA AND SLAVONIA}

Having been set free from the Turkish rule, some parts of Croatia remained very close to the Ottoman Empire. These circumstances caused a constant threat from numerous contagious diseases over the long bordering line which was difficult

\footnotetext{
${ }^{1}$ Ivan Beuc, Povijest institucija državne vlasti Kraljevine Hrvatske, Slavonije i Dalmacije, Zagreb 1985, 284.

${ }^{2}$ See Mirko Dražen Grmek, Bolesti u osvit zapadne civilizacije, Zagreb 1989, different chapters
} 
to control. This bordering line was used for live trading and many passengers used to cross it. ${ }^{3}$ There were also a few very frequent roads on which most of the traffic of goods and people with Ottoman Empire took place. ${ }^{4}$

The Austrian authorities were trying to control the flow of people and goods especially in times when there was an outbreak of epidemics of some contagious disease in the nearby parts of the Ottoman Empire. It is interesting that Austrian authorities used to send the so-called sanitatis exploratores to Turkish territories, that is spies who, among other things, reported to the Austrian authorities about health circumstances in Ottoman Empire, so that appropriate measures could be introduced..$^{5}$

One of the basic ways of prevention and combat against contagious diseases was the introduction of the so-called sanitary cordons towards the territory threating with a certain infection, which in this case meant towards the Turkish Empire. Sanitary cordons were organized as required and functioned in such a way as to physically prevent the flow of people, cattle and goods from potentially dangerous territories to the territory of Austrian Empire. If, by any chance, a certain disease appeared on the territory of Austrian Empire, then a sanitary cordon was set up between the infected areas and those not affected by the disease. The border, or any other area that could have been proclaimed a sanitary cordon, was controlled by armed soldiers ready to prevent any potential offenders using weapon and those who were trying to avoid sanitary cordon were facing a potential death penalty.

Sanitary cordons and quarantines were introduced very early, almost right after the liberation of Slavonia. Already in 1700, the Court War Council decided to introduce stronger measures of control and set up quarantines on the borders with Ottoman Empire, due to outbreak of plague in the vicinity of Belgrade and Timisoara. In the next few years, in 1707, 1708 and 1710, as a precaution for the outbreak of plague, sanitary cordons were introduced towards the Ottoman Empire, and the offenders who disobeyed the safeguard measures were facing death penalty. ${ }^{6}$

However, since even in those times it wasn't possible to stop communication and trade, the so-called lazarettos were established, where travellers and goods from the infected or suspicious areas had to spend a certain period of time, very often several weeks, after which they would prove to be either infected or not infected. The first traces of lazarettos in Croatia were found at the beginning of the $18^{\text {th }}$ century, when they were established on the border of Kingdom of Croatia and Slavonia. ${ }^{7}$

\footnotetext{
${ }^{3}$ see overview by Drago Roksandić, Vojna Hrvatska: La Croatie Militaire, Zagreb 1988, 58. - 97.

${ }^{4}$ Mirko Valentić, Hrvatsko-slavonska Vojna krajina 1790-1881, Zagreb 1984, 58.

${ }^{5}$ Robert Skenderović, „Kuga u Požegi i požeškoj kotlini 1739. godine“ Scrinia Slavonica, 1/2003, 161 .

${ }^{6}$ Stanko Gavrilović, Srem od kraja XVII. do sredine XVIII. veka, Novi Sad 1974, 239-241.

${ }^{7}$ Robert Skenderović, ibid
} 
Lazarettos were established on main border and traffic crossings from the Ottoman Empire into the Austrian Empire, and on the secondary and less busy crossings there were the so-called "rastels" with quarantines to stop the travelers being redirected to far-away lazarettos.

There were many lazarettos in Croatia, and sometimes they were established if necessary and in case of an epidemics outbreak. There were lazarettos in Slavonski Brod, Stara Gradiška and Kostajnica, and the most important one, carrying most of traffic towards the Ottoman Empire was Zemun.

The supervision on the border was organized by a series of "chardaks" (Croatian: "čardak"), which were a half-an-hour walking distance from each other and which had a crew of 6 to 10 armed border guards. They guarded the border day and night and supervised the traffic of people and cattle. If someone tried to enter illegally, they would be transported to a nearby "rastel" or lazaretto under weapon threat. At the attempt of swimming over the Sava river, the cattle was chased off by yelling, and if that proved to be unsuccessful, then they were shot and shoved away from the bank with a pole. ${ }^{8}$

During the first half of the 18th century, the Austrian authorities considered the territory of Slavonia and Srijem to be potentially dangerous for the spread of contagious diseases into the empire, so they often introduced special safeguard measures and organized sanitary cordons. Small-scale epidemics and occasional outbreaks of contagious diseases were very common, and the most dangerous was the plague epidemics in 1739. This epidemics affected The Lower town in Osijek, Cernik, Gradiška, and especially severely the town of Požega and Požega valley. $50 \%$ of the population in Požega died during the epidemics, and over 1300 people in Požega valley. ${ }^{9}$

Sanitary cordons were of big significance for the Austrian empire, which rests on the fact that, during a period of hundred years (from 1709 till 1800), thanks to sanitary cordons, the plague managed to spread through the empire only twice- in 1739 and in $1795 .^{10}$

One of the means of fighting contagious diseases in the Austrian empire was the establishment of Court Health Council in 1710 or 1711 as the central institution of health policy of the Austrian authorities, which had an advisory character during the process of fighting the outbreak and spread of contagious diseases. There were actually two councils- one for Austrian, and one for the Hungarian half of the monarchy. ${ }^{11}$

\footnotetext{
${ }^{8}$ Željka Perković, „Preventivno-zdravstvene građevine grada Slavonskog Broda“, Hrvatski časopis za javno zdravstvo, 7/2006, 1-14.

${ }^{9}$ Robert Skenderović, o. c., 165.

${ }^{10}$ Robert Skenderović, ibid.

${ }^{11}$ Robert Skenderović, „Zdravstvene reforme Marije Terezije u Slavonskom provincijalu i Generale normativum sanitatis iz 1770“, Scrinia slavonica, 5/2005, 127
} 
During the 1740s two health committees were founded- one in Osijek, and the other one in Karlovac. These committees were responsible for supervising the situation in sanitation and functioning of sanitary cordons. Karlovac committee was responsible for supervising the situation in sanitation on the territory of Karlovac generalate, and Osijek committee for the territory of Slavonian Krajina and three Slavonian counties- Srijem-, Požega- and Virovitica-county.

Karlovac committee had the jurisdiction in controlling the lazarettos in Slunj and Radanovac, and Osijek committee supervised the functioning of lazarettos in Zemun, Mitrovica, Brod and Stara Gradiška.

In 1756 Zagreb sanitary committee was established as well, it had jurisdiction over the territory of Varaždin generalate and Croatian counties and it supervised the functioning of the lazaretto in Kostajnica. ${ }^{12}$

Continuous care for implementing sanitary policy and preventing the spread of contagious diseases into the Austrian empire resulted in introducing general health act Generale Normativum Sanitatis in 1770 by the empress Maria Therese. This act encompassed many other health regulations introduced by former rulers and it represented the fundamental health regulation for all empire.

This Act stipulated establishing sanitary committees which were supposed to be made up of experts and which were to report to the Court sanitary committee in Vienna about their decisions. The existing sanitary committees in Osijek, Zagreb and Karlovac already fitted into the plan designed by this Act.

Generale Normativum Sanitatis counted several regulations and in a clear and precise way regulated the functioning of cordons. ${ }^{13}$

During the first half of the $19^{\text {th }}$ century in Osijek and Slavonia there was often the danger of an outbreak of cholera epidemics. The national and city authorities introduced many measures against that outbreak, as recorded in numerous reports and instructions in archival fonds City Government of the free royal city of Osijek.

During the second half of the $19^{\text {th }}$ century the situation in public health system was very bad. One physician was responsible for many more people than in any other parts of the Monarchy. Midwifery, pharmacy, veterinary and sanitary services were low on the scale and the death rate of newborns was extremely high. ${ }^{14}$

\section{MAŽURANIĆ REFORMS IN PUBLIC HEALTH}

Croatian-Hungarian Settlement created legal frames for independent regulation of many aspects of everyday life, including healthcare.

\footnotetext{
${ }^{12}$ Robert Skenderović, o. c., 128.

${ }^{13}$ Robert Skenderović, o. c., 141.

${ }^{14}$ Mirjana Gross, Agneza Szabo, Prema hrvatskome građanskom društvu, Zagreb 1992, 401.
} 
Along with all these circumstances, a very important year was 1873, when Ivan Mažuranić was appointed the "Ban" (governor) of Croatia. Before his appointment as Ban, Mažuranić had performed many different functions related to administration and judiciary. Back in 1849, together with Metel Ožegović and Herman Bužan, he was the counsellor of the Austrian minister of justice Schmerling, and he participated in the work of a special committee for reorganization of juridical system lead by Maksimilijan Rušnov. ${ }^{15}$ For more than a decade Mažuranić performed many duties in Croatian and Austrian administrative system which made him a well-informed official who was familiar with the system of decision-making and acting into details, and so he was able to invest all that knowledge into the prosperity of Croatia. ${ }^{16}$ His constant reformatory and modernizing acting resulted in great administrative, juridical, and educational reforms during his rule as Ban from 1873-1880. ${ }^{17}$ The period of his rule as Ban was marked with continuous reformatory and modernizing ideas and acts. Precisely during that period, Croatia was introduced to a lot of new and modern heritage in different areas like judiciary, education, administration and healthcare. In relatively short time, a series of acts and laws were passed which dealt with certain issues rather differently than ever before. Mažuranić was very much aware that the possibility for him to act as Ban was a chance to finalize his longtime work in public administration in a thorough reformatory work and introduction of new, modern principles into many segments of public life in Croatia, including the healthcare.

The first step on the way was the implementation of the Law on the Organization of Health in Croatia and Slavonia, along with a series of regulations regulating in more detail specific issues in the scope of public health.

Competences and activities in the field of public health are described in detail in the document named The Health Organization Act in Croatia and Slavonia, written in $1874 .^{18}$

Royal Croatian-Slavonian-Dalmatian Provincial Government was the supreme body for public health care in Croatia and Slavonia.

At the lower levels, the care of law implementation and the decisions of the Government were handled by political sectors, namely, sub-counties and cities, that is, municipalities with an appointed officer. For this purpose, sub-counties appointed sub-county doctors and poultrymen, and in cities, special bodies subject for health were selected by city representatives.

${ }^{15}$ Anto Milušić, Historiografski triptih, Osijek 1998, 56.

${ }^{16}$ Dalibor Čepulo, „Središte i periferija: europske i hrvatske odrednice Mažuranićevih reformi ustrojstva vlasti i građanskih prava (1873-1880)“, Zbornik Pravnog fakulteta u Zagrebu, 6/2000 Zagreb, 901.

${ }^{17}$ Čepulo, Dalibor, ibidem

${ }^{18}$ Sbornik zakonah i naredaba, 435/1874. 
Certain political municipalities have undertaken a range of activities to pursue activities within the scope of public health; enforced regulations on roads, streets, roads, markets, squares, canals, restrooms, running and standing water, public baths, etc. They also took care of patients, childbirths and accidents. Keep records of deaf persons and persons with mental disabilities in the institutions. They organize and maintain mortuaries and cemeteries, and take care of the examination of the dead. They also take care of the health of slaughterhouses and the supervision of livestock fairs.

Political municipalities also got administrative tasks entrusted to them by the Government.

Sub-county doctors conducted a range of tasks in the implementation of public health activities in each sub-county; managed the health and medical staff employed by the state, municipal and private service in the sub-county, supervised the implementation of health regulations, as well as the regulations on adrenal medicine, the sale of poisons and medicines, the supervision of bathing sites, the monitoring and vaccination against measles, regular supervision of hospitals, implementation of measures to curb and control human and animal infectious diseases, etc.

The provisions of this law also specify that in addition to the above-mentioned medical staff, the required number of midwifery graduates with a passing exam should be employed in the area of each administrative area.

The National Health Council was also appointed, which was the government's advisory body in all matters relating to health. This panel was made up of regular members: a government health rapporteur, a ground veterinarian, and at least four doctors, along with extraordinary members who were appointed as needed on a case by situation basis. Regular members are appointed for a term of three years.

In addition to this fundamental law, several guidelines and provisions have been chosen regulating particular areas of public health in more detail, thus creating a genuinely useful network of regulations controlling that area. Among the most important are: Instruction for sub-county physicians and city physicists ${ }^{19}$, Order against excessive blood leakage, Law on the organization of a midwifery college in Zagreb, Order on the admission of pregnant women to midwives, Instruction for livestock breeders, Order for pharmacy choirs, Regulation on domestic pharmacies, Order concerning medicinal quotient, Order on handling and trade in poisons, Order on sightseeing of meat, Order on spoiling and spoiling of beverages, Order on vaccination against smallpox, Instruction on how to deal with the general population of chickens in general and cholera, Ordinance on the public supply of the poor in their municipality, but also in the paupers and health institutions, the Ordinance on the regulation of bathing activities, the quantity of patients in a terrestrial hospital, the Ordinance on the inspection of the dead, the

\footnotetext{
${ }^{19}$ Milivoj Vežić, Pomoćnik za javnu upravu, Zagreb 1884, 314.
} 
Ordinance on the transport of the deceased, the Bovine Plague Proceedings, the Circular Against Cattle Monsters, etc. ${ }^{20}$

In 1894 a new law was passed on the health service organization in the Kingdoms of Croatia and Slavonia. ${ }^{21}$ After twenty years of implementation of the law of 1874 , the need to pass a new law has emerged to comply with the territorial and administrative changes that have been implemented.

There has been a reintegration of the Military Krajina and significant reforms in the administrative system, so the new law aligns the state of public health with the regulatory system in Croatia and Slavonia.

Thus, under provisions of law mentioned before, the Provincial Government is also competent for the management and control of all public health activities in the territory of the Kingdom of Croatia and Slavonia. Within the Government, there was a separate health department and a Ground Health Council to carry out these activities.

In the territories of counties and cities, these activities were performed by county physicists and county health boards, concerned city doctors, city health boards and midwives, and in the districts by county doctors. ${ }^{22}$

The main intention of the legislator was that the introduction of county and city health committees took into account the facts about the specific situation on the ground, ie, in individual county and city, and thus implemented better and more efficiently the measures of state authorities on public health care. ${ }^{23}$

It also stipulates that in cities of up to 5,000 inhabitants, one doctor should be appointed, up to 10,000 two, up to 20,000 three, and over 20,000 for each further 10,000 inhabitants, one doctor. ${ }^{24}$

Particular care continued to be given to the emergence and control of infectious diseases, so in the event of the occurrence of the same county and city health committees become so-called monster committees that have all the authority to fight an epidemic.

The veterinary profession has proven to be an essential activity in the field of public health care. There were frequent outbreaks of livestock diseases (mainly bovine plague), causing enormous economic damage, and the state took a serious approach to combat epidemics and regulating the veterinary service. The 1874 law governing the health profession treated the veterinary profession as an up-to-date health profession and did not control it sufficiently in detail. The territorial and administrative changes already mentioned in the Kingdoms of Croatia and Slavonia have also occurred, so the situation in the veterinary profession needed to

${ }^{20}$ Milivoj Vežić, op. c., 320-579.

${ }^{21}$ Sbornik zakonah i naradaba, 9/1894

${ }^{22}$ Sbornik zakonah i naredaba, 2/1894.

${ }^{23}$ Milan Smrekar, Priručnik za političku upravnu službu, Zagreb 1899, 178.

${ }^{24}$ Sbornik zakonah i naredaba, 26/1894. 
be brought into line with the real situation and regulated in a better, more modern and efficient way. Besides, Hungary adopted a new veterinary law that was in line with Austrian law and introduced into the territory of Bosnia, so that a new law regulating the veterinary service in both Croatia and Slavonia was a necessity. ${ }^{25}$

By these laws and regulations, a rather advanced system of legal control and public health care was introduced in Croatia and Slavonia at that time, which remained in force until the dissolution of the Austro-Hungarian Monarchy. There have been minor changes, but they have not touched on the essence of a public health system established in this way.

A particular contribution of the Acts of 1874 and 1894 was that they introduced a relatively modern public health system in Croatia, compatible with the administrative system. Such a system enabled the care of all segments of public health in the territory of Croatia and Slavonia in an efficient manner, which was supported by a reliable and well established administrative system and governing bodies.

It is important to emphasize that special care was devoted to the protection and prevention of infectious diseases (monsters). Both human, especially plague, cholera and smallpox, and livestock, especially bovine plague, so the occurrence of these was rare.

\section{CONCLUSION}

Reforms in public health carried out during the rule of Ban Mažuranić represented a big step forward in comparison to the situation before. Many segments of public health care were legally regulated in previously non-regulated territories.

This reform was merely one in a broad spectrum of reforms introduced by Ban Ivan Mažuranić, which greatly improved the quality of life in Croatia.

\section{REFERENCES}

Ivan Beuc, Povijest institucija državne vlasti Kraljevine Hrvatske, Slavonije i Dalmacije, Zagreb 1985.

Mirko Dražen Grmek, Bolesti u osvit zapadne civilizacije, Zagreb 1989.

Drago Roksandić, Vojna Hrvatska: La Croatie Militaire, Zagreb 1988.

Mirko Valentić, Hrvatsko-slavonska Vojna krajina 1790-1881, Zagreb 1984.

Robert Skenderović, „Kuga u Požegi i požeškoj kotlini 1739. godine“ Scrinia Slavonica, $1 / 2003$.

Stanko Gavrilović, Srem od kraja XVII. do sredine XVIII. veka, Novi sad 1974.

${ }^{25}$ Milan Smrekar, op.c., 214-215. 
Željka Perković, „Preventivno-zdravstvene građevine grada Slavonskog Broda“, Hrvatski časopis za javno zdravstvo, 7/2006.

Robert Skenderović, „Zdravstvene reforme Marije Terezije u Slavonskom provincijalu i Generale normativum sanitatis iz 1770", Scrinia slavonica, 5/2005.

Mirjana Gross, Agneza Szabo, Prema hrvatskome građanskom društvu, Zagreb 1992.

Anto Milušić, Historiografski triptih, Osijek 1998.

Dalibor Čepulo, „Središte i periferija: europske i hrvatske odrednice Mažuranićevih reformi ustrojstva vlasti i građanskih prava (1873-1880)“, Zbornik Pravnog fakulteta u Zagrebu, 6/2000 Zagreb.

Sbornik zakonah i naredaba, 435/1874.

Milivoj Vežić, Pomoćnik za javnu upravu, Zagreb 1884, 314.

Sbornik zakonah i naradaba, 9/1894.

Milan Smrekar, Priručnik za političku upravnu službu, Zagreb 1899. 
Др Миро А. Гарgащ, реgовни йрофесор

Универзитетеи J.J. Шииросмајер Осијек

Правни факулиетеи Осијек

mgardas@pravos.hr

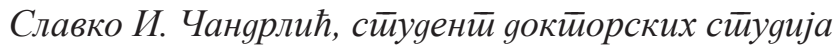

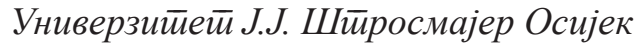

Правни факулиетей Осијек

slcandrlic@gmail.com

\section{Законодавна регулатива јавног здравства у Хрватској у другој половини 19. века}

Сажетиак: У одреgбама Хрвайско-уїарске найоgбе из 1868. унуйарња уйрава смайрана је јеgним о а ауйономних иооручја која је Хрвайска сама реїулирала. Дио йоїа било је и јавно здравстиво, које је gо йаgа било реїулирано на врло застиарјели начин. Каgа је Иван Мажуранић именован хрвайским баном, ойворен је йуй за значајне реформе у бројним йоgручјима јавноі и

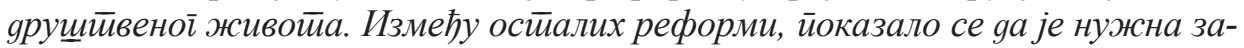

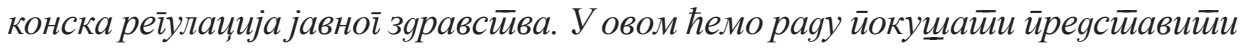

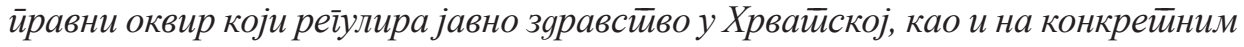

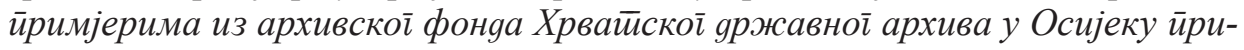
казайи како су се тии закони иримењивали у свакодневном живойуу.

Кључне речи: јавно здравстиво, реформа, Мажуранић, Осијек, Славонија.

Датум пријема рада: 24.04.2020. 